УДК 37:33(571)(09)

ББК 74:65(253)г

DOI 10.17150/2308-2588.2017.18(3).443-464

\title{
КОММЕРЧЕСКОЕ ОБРАЗОВАНИЕ В СИБИРИ И НА ДАЛЬНЕМ ВОСТОКЕ В НАЧАЛЕ ХХ ВЕКА B ОТРАНЕНИИ РЕТРОСПЕКТИВНОЙ БИБЛИОГРАФИИ
}

Аннотащия. Публикация знакомит с изданиями 1900-1920 гг., отражающими развитие в рассматриваемый период коммерческого образования на пространстве Сибири и Дальнего Востока. В основу подборки / выборки, адресованной историкам коммерческого / экономического образования, положены библиографические материалы, отраженные в сводном каталоге / базе данных ГПНТБ СО РАН «Сибирская и дальневосточная книга. XVIII в. - 1930 г.».

Ключевые слова. История коммерческого образования, Сибирь, Дальний Восток, ретроспективная библиография.

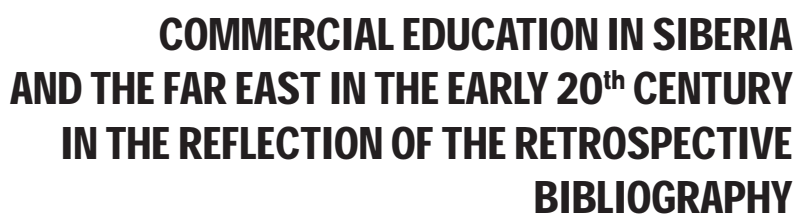

Abstract. The article reviews 1900-1920 publications that reflect the development of commercial education in Siberia and the Far East during these years. The basis of selection / sampling that is addressed to historians of commercial / economic education based on bibliographic materials, as reflected in the master catalog / database of The State Public Scientific Technological Library of the Siberian Branch of the Russian Academy of Sciences (SPSTL SB RAS) «Siberian and Far Eastern book XVIII c. 1930».

Keywords. History of commercial education, Siberia, the Far East, retrospective bibliography. 
Вряд ии ошибемся, утверждая, что ретроспективные библиографические указатели вот уже второе столетие верой и правдой служат не только надежным путеводителем $b$ исторических разысканиях, но и незаменимым источником исторической / историографической инорормации. Конеи, прошлого и начало нынешнего века (по крайней мере, в нашей стране), когда на смену каталогам, картотекам и печатным указателям стали приходить компьютерные базы данных, качественно изменили эвристический потенииал ретроспективной библиографии. Призванный поначалу всего лишь упростить и ускорить процесс создания печатных изданий, новый инструментарий, особенно с появлением поисковых систем, принципиально растирил возможности извлечения из «недр» последней интересующей историка информации.

Путь от печатного каталога ${ }^{1} \kappa$ библиографической базе данных $x^{2}$ в предельно короткие сроки проделал и фрундаментальный «Сводный каталог сибирской и дальневосточной книги (XVIII в. - 1930 г.)», составленный ГПНТБ СО РАН при участии крупнейших общенациональных книгохранилищ, и библиотек региона. В предваряющей публикацию каталога заметке составители подчеркивают, что «это универсаль-

${ }^{1}$ Сводный каталог сибирской и дальневосточной книги. 1790-1917 гг.: в 3 т. / Сиб. отд-ние РАН, Гос. публ. науч.-техн. б-ка; [отв. сост. Р. Е. Павлова; науч. ред.: Е. Б. Соболева]. - Новосибирск: ГПНТБ СО РАН, 2004-2005. - Т. 1: 1790-1900. - 2004. 506, [1] с.; Т. 2: 1901-1917. - 2004. - 709 с.; Т. 3: Вспомогательные указатели. - 2005. - 490 с.; Сводный каталог сибирской и дальневосточной книги. 1918-1930 гг.: в 2 т. / Гос. публ. науч.-техн. б-ка Сиб отд-ния Рос. акад. наук; [сост.: Л. А. Мандринина и др.; науч. ред.: И. А. Гузнер]. - Новосибирск: ГПНТБ СО РАН, 20142015. - Т. 1. - 2014. - 749, [1] с.; Т. 2: Вспомогательные указатели. $-2015 .-609$ с.

2 Библиографическая база данных ГПНТБ СО РАН «Сибирская и дальневосточная книга. XVIII в. - 1930 г.» [свод. кат.] // Режим доступа: http://webirbis.spsl.nsc.ru/irbis64r_01/cgi/ cgiirbis_64.exe?C21COM=F\&I21DBN=SDVB\&P21DBN=SDVB\&S21 $\mathrm{FMT}=\& S 21 \mathrm{ALL}=\& Z 21 \mathrm{ID}=\& S 21 \mathrm{CNR}=20$ Хронологический охват: Ч. 1. XVIII в. - 1917 г., Ч. 2. 1918-1930. Объем: 27851 запись. Тематический охват: универсальный. БД представлена на сайте ГПНТБ СО РАН через Web-ИРБИС. 
ное по содержанию библиографическое пособие, отражающее документы по различным областям знания, что позволяет не только представить полную картину издательской деятельности в Сибири, но и проследить динамику развития науки, промышленности, культуры, общественно-политических движений и т. д.»³. В прошедшие с момента его «выхода $b$ свет» годы В указанном порядке фактически и шло включение материалов сводного каталога В научный оборот. Первыми интерес к нему проявили историки книжного / издательского дела В Сибири и на Дальнем Востоке, предпринявшие исследования, которые расширили представления об исторической географии книгоиздания $b$ регионе, позволили установить закономерности возникновения и развития книжного дела в его крупных географических и экономических районах. Думается, однако, что настала пора взглянуть на возможности каталога с точки зрения отражения им «динамики развития» и других сфер жизни региона, в нашем случае - коммерческого образования.

Публикуемая на страницах журнала подборка / выборка адресована преимущественно исследователям истории коммерческого / экономического образования в Сибири и на Дальнем Востоке, которая все еще не выила из стадии «краеведческого» описания отдельных учебных заведений. А потому, не только и не столько преследует цель привлечь внимание к конкретным изданиям $b$ неи и, следовательно, $b$ «Сводном каталоге...» отраженным, или месту их хранения (что, безусловно, важно само по себе), сколько побудить к созданию общей картины возникновения и развития коммерческого образования на востоке страны. Именно этой цзелью объясняются - пусть и крайне незначительные - дополнения к непополняемому каталогу или расширение выборки за счет учебных изданий существовавших в регионе высших учебных заведений и частных коммерческих курсов, ответственность за что публикатор возлагает исключительно на себя.

${ }^{3}$ От составителей / / Сводный каталог сибирской и дальневосточной книги. 1790-1917 гг.: в 3 т. Т. 1: 1790-1900. - С. 5. 
1. Соболев М. Н. Коммерческая география России : очерк хоз. статистики / М. Н. Соболев. - Томск : [б. и.], 1900. - II,263 с.

Держатели документа: Научная библиотека Томского государственного университета.
\end{abstract}

\title{
costos
}

2. Кохановский Н. И. Конспект курса политической экономии : 1900/01 гг. / Н. И. Кохановский. Владивосток : [б. и.], 1901. - 13, 284 с. Литогр. Справ. кн. по Вост. ин-ту в г. Владивостоке на 1909 г. Владивосток, 1909.

3*. Устав Томского коммерческого училища, учрежденного Томским купеческим обществом. - Томск : Тип. К. А. Орлова, 1901. - 16 с. ${ }^{4}$

Держатели документа: Научная библиотека Томского государственного университета.

4. Соболев М. Н. Коммерческая география России : очерк хоз. статистики и географии России сравнительно с иностр. государствами / М. Н. Соболев. - 2-е изд., испр. и доп. - Томск : Тип. П. И. Макушина, 1902. III, 244 c.

Держатели документа: Научная библиотека Томского государственного университета; Научная библиотека Иркутского государственного университета; Российская государственная библиотека.

\section{3}

5. Кохановский Н. И. Записки по курсу политической экономии : литогр. лекции / Н. И. Кохановский ;

4 Здесь и далее звездочкой $\left(^{*}\right)$ отмечены издания, отсутствующие в базе данных, но отраженные в электронных каталогах библиотек-держателей документа. 
Вост. ин-т. - Владивосток : [б. и.], 1903. - 116 с. Справ. кн. по Вост. ин-ту в г. Владивостоке на 1909 г. Владивосток, 1909.

6. Кохановский Н. И. Очерк экономического положения Японии / Н. И. Кохановский ; Вост. ин-т. Владивосток : [б. и.], 1903. - 2, 130, IV с.

Держатели документа: Новосибирская государственная областная научная библиотека; Российская государственная библиотека; Российская национальная библиотека.

7. Кюнер Н. В. Коммерческая география Китая. Обзор открытых портов в связи с их ролью во внешней торговле Китая : лекции, чит. на 4-м курсе Вост. ин-та в 1902/03 акад. г. / Н. В. Кюнер ; изд. П. Шкуркина. Владивосток : [б. и.], 1903. - 182 с. Мимеогр.

Держатели документа: Российская государственная библиотека; Российская наииональная библиотека.

8. Обзор коллекций торгово-промышленного музея при Восточном институте / сост. В. И. Зазерский. Владивосток : [б. и.], 1903. - 83 с.

Держатели документа: Научная библиотека Иркутского государственного университета.

\section{c)}

9. Дмитриев Н. Н. Лекции по товароведению, читанные в Восточном институте в 1906 академическом году / Н. Н. Дмитриев ; Изд. студентом А. Занковским и слушателем Вост. ин-та кап. Л. Орловым. - Владивосток : [б. и.], 1906. - 4 с. На правах рукописи. Справ. кн. по Вост. ин-ту в г. Владивостоке на 1909 г. Владивосток, 1909.

\section{c)}

10. Дмитриев Н. Н. Лекции по товароведению, читанные в Восточном институте в 1906/07 академи2017. T. 18, № 3. C. 443-464 
ческом году / Н. Н. Дмитриев ; Изд. студентом А. Занковским и слушателем Вост. ин-та кап. Л. Орловым. Владивосток : [б. и.], 1907. - 8 с. На правах рукописи. Справ. кн. по Вост. ин-ту в г. Владивостоке на 1909 г. Владивосток, 1909.

11. Любомудров. Тетрадь бухгалтерских арифметических примеров. - Иркутск: Тип. Т-ва печ. дела, 1907. - 57 с. Кн. летопись. 1907. № 1847.

12. Таберио Н. Конспект лекций по политической экономии, читанных в Восточном институте в 1906/07 академическом году / Н. Таберио ; сост. слушателями. - Владивосток : [б. и.], [1907]. - 176 с. Литогр. Справ. кн. по Вост. ин-ту в г. Владивостоке на 1909 г. Владивосток, 1909.

13*. Устав Иркутского коммерческого училища. Иркутск : Тип. М. П. Окунева, 1907. - 24 с.

Держатели документа: Научная библиотека Иркутского государственного университета.

14. Устав Общества Иркутского коммерческого училища. - Иркутск : [б. и.], 1907. - 17 с.

Держатели документа: Иркутская областная публичная библиотека им. И. И. Молчанова-Сибирского.

\section{8}

15. Дмитриев Н. Н. Обозрение лекций по товароведению, читанных преподавателем коммерческих наук при Восточном институте Н. Н. Дмитриевым в 1907/08 академическом году / Н. Н. Дмитриев. - Владивосток : [б. и.], 1908. - 20 с. Литогр. Тираж 100 экз.

Держатели документа: Российская государственная библиотека; Российская национальная библиотека.

16. Краткий отчет о состоянии учебно-воспитательной части во втором коммерческом училище в го- 
роде Иркутске за 1907/08 учебный год : 1-й год существования уч-ща. - Иркутск : [б. и.], 1908. - 34 с.

Держатели документа: Иркутская областная публичная библиотека им. И. И. Молчанова-Сибирского.

17. Кюнер Н. В. Конспект лекций коммерческой географии стран Дальнего Востока : 1907/08 акад. г. / Н. В. Кюнер ; изд. кап. Кравцова. - Владивосток : [б. и.], [1908]. - 82 с. Гектогр. Справ. кн. по Вост. ин-ту в г. Владивостоке на 1909 г. Владивосток, 1909.

18. Программа и правила бухгалтерских курсов при общественном вспоможении приказчиков в Иркутске, открытых в 1908 году. - Иркутск : Тип. М. П. Окунева, 1908. - 14 с. Тираж 400 экз. Кн. летопись. 1908. № 7067.

19. Устав Общества родителей и учителей воспитанников 1-го Сибирского коммерческого училища цесаревича Алексея. - Томск : Тип. Губерн. упр., 1908. - 8 с. Тираж 500 экз.

Держатели документа: Российская национальная библиотека.

\section{c)}

20. Кохановский Н. И. Краткое обозрение системы мер и денег в Китае / Н. И. Кохановский. - Владивосток : Тип. Вост. ин-та, 1909. - 9 с. Отт. из Изв. Вост. ин-та. 1909. Т. 29, вып. 2. Тираж 250 экз.

Держатели документа: Научная библиотека Томского государственного университета; Научная библиотека Иркутского государственного университета; Научная библиотека Дальневосточного государственного университета; Российская государственная библиотека.

21. Кохановский Н. И. Политическая экономия. Вып.1: Введение : Лекции, чит. в Вост. ин-те / Н. И. Кохановский. - Владивосток : [б. и.], 1909. - 84 с. Литогр. 2017. T. 18, № 3. С. 443-464 
Держатели документа: Российская государственная библиотека; Россииская национальная библиотека.

22. Кохановский Н. И. Политическая экономия. Вып.3: Особенная часть / Н. И. Кохановский. - Владивосток : [б. и.], 1909. - 2, 132 с. Литогр.

Держатели документа: Российская государственная библиотека; Россииская национальная библиотека.

23. Кюнер Н. В. Коммерческая география Китая. Вып. 1, отд. 1: Введение к общему курсу. Характеристика литературы предмета. Население. Климат. Сельское хозяйство. Добывающая и обрабатывающая промышленность. Отд. 2: Внутренняя торговля и пути сообщения : лекция по коммер. географии стран Дал. Востока, чит. в Вост. ин-те в 1908/09 акад. г. / Н. В. Кюнер. Владивосток : Тип. Вост. ин-та, 1909. - 99 с. Литогр.

Держатели документа: Новосибирская государственная областная научная библиотека; Научная библиотека Иркутского государственного университета.

24. Соболев М. Н. Коммерческая география России / М. Н. Соболев. - 5-е изд. - Томск : Тип. Сиб. т-ва печ. дела, 1909. - VI, 263 с.

Держатели документа: Российская государственная библиотека; Россииская национальная библиотека.

\section{cos}

25. Обзор коллекций торгово-промышленного музея при Восточном институте : доп. и изм. / сост. Н. Н. Дмитриев. - Владивосток : Тип. Вост. ин-та, 1910. - II, 36 с. Тираж 304 экз.

Держатели документа: Научная библиотека Иркутского государственного университета; Российская государственная библитека.

26. Отчет Владивостокского коммерческого училища Министерства торговли и промышленности за 
1908/09 и 1909/10 учебные годы. - Владивосток : Тип. Н. П. Матвеева, 1910. - 188 с.

Держатели документа: Дальневосточная государственная научная библиотека; Российская государственная библиотека; Российская национальная библиотека.

27. Отчет о состоянии учебно-воспитательной части Иркутского коммерческого училища за 1908/09 учебный год. - Иркутск : [б. и.], 1910. - 4, 49 с.

Держатели документа: Государственный архив Иркутской области; Российская государственная библиотека; Российская национальная библиотека.

28. Первое Сибирское коммерческое училище цесаревича Алексея. - Томск : [б. и.], 1910. - 176 с.

Держатели документа: Новосибирская государственная областная научная библитека.

29. Рудаков А. В. Китайские разговоры официального и коммерческого характера : руководство к пер. с рус. на кит. яз.: сост. по Гуань-хуа чжи-нань, с некоторыми изм. для студентов 2-го курса Вост. ин-та. Вып.1: Диалоги / А. В. Рудаков. - Владивосток : Тип. Вост. ин-та, 1910. - 48 с. На рус. и кит. Тираж 250 экз.

Держатели документа: Российская государственная библиотека; Российская национальная библиотека.

30. Рудаков А. В. Китайские разговоры официального и коммерческого характера : руководство к пер. с рус. на кит. яз.: сост. по Гуань-хуа чжи-нань, с некоторыми изм. для студентов 2-го курса Вост. ин-та. Вып. 2 / А. В. Рудаков. - Владивосток : Тип. Вост. инта, 1910. - 64 с.

Держатели документа: Российская государственная библиотека; Российская национальная библиотека.

31. Устав Общества попечения об учащихся при Владивостокском коммерческом училище. - Владивосток : Тип. А. К. Петрова, 1910. - 18 с. Тираж 510 экз. Тираж 510 экз. Кн. летопись, 1910, № 7801. 
32. Устав первой Сибирской торговой школы при Обществе взаимного вспоможения приказчиков в Томске. - Томск : Тип. Сиб. т-ва печ. дела, 1910. - 14 с.

Держатели документа: Российская государственная библиотека; Российская национальная библиотека.

33. Устав частного коммерческого училища Колокольниковых в Тюмени : утв. 10 апр. 1910 г. - Тюмень : Тип. «Сиб. торг. газ.» (А. А. Крылова), 1910. - 18 с.

Держатели документа: Научная библиотека Тюменского областного краеведческого музея.

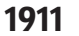

34. Николаенко П. М. Материалы по коммерческому образованию в Японии : по яп. ист. / П. М. Николаенко. - Владивосток : Тип. Вост. ин-та, 1911. - LII, 92 с. Отт. из Изв. Вост. ин-та, 12-й год изд., 1910/11 акад. г. Т. 37, вып.2. Тираж 300 экз.

Держатели документа: Научная библиотека Томского государственного университета; Российская государственная библиотека; Российская национальная библиотека.

35. Отчет Омского коммерческого училища за 1909/10 учебный год. - Омск : [б. и.], 1911.

Держатели документа: Библиотека Государственного архива Омской области.

36. Примерная программа для поступления в младшее и старшее отделения приготовительного класса, первый, второй и третий классы 1-го Сибирского коммерческого училища цесаревича Алексея в городе Томске. - Томск : Тип. Приюта и Дома трудолюбия, 1911. - 17 с. Тираж 300 экз. Кн. летопись, 1911, № 19215.

37. Рудаков А. В. Китайские разговоры официального, коммерческого и частного характера. Вып.3 : руководство к пер. с рус. на кит. яз.: сост. по Гуань-хуа чжи-нань с некоторыми изм. для практ. изуч. кит. яз. в 
Вост. ин-те / А. В. Рудаков. - Владивосток : Тип. Вост. ин-та, 1911. - 113, 26 с. Тираж 200 экз.

Держатели документа: Российская государственная библиотека.

38. Рудаков А. В. Очерк торгово-промышленной деятельности Китая : пособие к лекциям, чит. в 1910/11 акад. г. Вып.1 / А. В. Рудаков. - Владивосток : Тип. Вост. ин-та, 1911. - 2, 56 с. Тираж 160 экз.

Держатели документа: Российская государственная библиотека; Российская национальная библиотека.

39. Состоящие в ведении Министерства народного просвещения курсы бухгалтерии, коммерческих вычислений и коммерческой корреспонденции А. П. Степанова. - Омск : Тип. «Иртыш», 1911. - 8 с. Кн. летопись. 1911. № 25043.

40. Степанов А. П. Курс коммерческих и финансовых вычислений / А. П. Степанов. - Омск : Тип. «Иртыш», 1911. - 129, 6 с.

Держатели документа: Омская государственная областная научная библиотека им. А. С. Пушкина; Российская государственная библиотека; Российкая национальная библиотека.

41. Устав Общества вспомоществования недостаточным ученикам Омского коммерческого училища. - Омск : Тип. «Иртыш», 1911. - 16 с. Тираж 1000 экз.

Держатели документа: Российская государственная библиотека; Российская национальная библиотека.

42. Устав Общества вспомоществования нуждающимся учащимся частного коммерческого училища братьев Колокольниковых в Тюмени. - Тюмень : Тип. А. А. Благинина и $\mathrm{K}^{\circ}, 1911 .-20$ с.

Держатели документа: Научная библиотека Тюменского областного краеведческого музея. 
43. Ченцов Н. В. Учебные программы первой Сибирской торговой школы при Обществе взаимного вспоможения приказчиков в городе Томске / Н. В. Ченцов ; Попечит. совет шк. - Томск : Тип. Н. И. Орловой, 1911. - 33, 1 с. Кн. летопись. 1911. № 1886.

44. Кюнер Н. В. Статистико-географический и экономический очерк Кореи, ныне японского генерал-губернаторства Циосень. Вып.1, ч.1: Статистико-географический очерк Кореи. Ч. 2: Экономический очерк Кореи. Отд.1: Сельское хозяйство / Н. В. Кюнер. Владивосток : Тип. Вост. ин-та, 1912. - VI, XVI, 656, 32 с. Тираж 570 экз.

Держатели документа: Государственная публичная научно-техническая библиотека СО РАН; Новосибирская государственная областная научная библиотека; Научная библиотека Томского государственного университета; Научная библиотека Иркутского государственного университета; Приморская государственная публичная библиотека им. А. М. Горького; Дальневосточная государственная научная библиотека; Научная библиотека Дальневосточного государственного университета; Научно-справочная библиотека Государственного архива Хабаровского края; Российская государственная библиотека; Российская национальная библиотека.

45. Отчет Общества вспомоществования бедным учащимся частного коммерческого училища Колокольниковых в Тюмени за 1911 год. - Тюмень : Тип. Л. И. Альтшуллера, 1912. - 7 с.

Держатели документа: Научная библиотека Тюменского областного краеведческого музея.

46. Отчет Омского коммерческого училища за 1910/11 учебный год. - Омск : [б. и.], 1912. 
Держатели документа: Библиотека Государственного архива Омской области.

47. Отчет о состоянии учебно-воспитательной части Иркутского коммерческого училища за 1909/10 и 1910/11 учебные годы : 2-й и 3-й год существования учща. - Иркутск : [б. и.], 1912. - 24, 34 с.

Держатели документа: Иркутская областная публичная библиотека им. И. И. Молчанова-Сибирского; Государственный архиВ Иркутской области; Российская государственная библиотека.

48. Отчет торговых классов Омского биржевого общества за 1911/12 учебный год. - Омск : Тип. «Художественная», 1912. - 23 с.

Держатели документа: Омская государственная областная научная библиотека им. А. С. Пушкина; Российская государственная библиотека.

49. Рудаков А. В. Программа преподавания в Восточном институте по предмету торгово-промышленной деятельности Китая / А. В. Рудаков. - Владивосток : Тип. Вост. ин-та, 1912. - 13 с.

Держатели документа: Научная библиотека Иркутского государственного университета; Российская национальная библиотека.

50. Устав Омской городской торговой школы. Омск : Тип. «Художественная», 1912. - 16 с.

Держатели документа: Омская государственная областная научная библиотека им. А. С. Пушкина.

51. Устав торговых классов при первом Сибирском среднем политехническом училище в городе Томске. - Томск : Тип. Н. И. Орловой, 1912. - 10 с. Тираж 100 экз.

Держатели документа: Российская государственная библиотека; Российская национальная библиотека. 2017. T. 18, № 3. C. 443-464 


\section{3}

52. Колотилин А. П. Книга для орфографических и грамматических упражнений по русскому языку Омского коммерческого училища. Вып.4,5 : Курс 2-го и 3-го кл. / А. П. Колотилин, А. Сливко. - Омск : Тип. «Печ. искусство», 1913. - 26 с. Тираж 200 экз.

Держатели документа: Российская государственная библиотека.

53. Кохановский Н. И. Политическая экономия. Вып.2: Общая часть : Лекции, чит. в Вост. ин-те, 1912/13 гг. / Н. И. Кохановский. - Владивосток : Тип. Вост. ин-та, 1913. - 349 с. Литогр. Е. А. Пановой. Тираж 150 эКз.

Держатели документа: Приморская государственная публичная библиотека им. А. М. Горького; Российская государственная библиотека; Российская национальная библиотека.

54. Краткие сведения и программы для поступающих в Омскую торговую школу. - Омск : Тип. «Иртыш», 1913. - 12 с. Тираж 400 экз. Кн. летопись. 1913. № 13854 .

55. Кюнер Н. В. Программы преподавания в Восточном институте [I : По общему курсу географии и этнографии Китая, Кореи и Японии. II : По новейшей (XIX века) истории Китая, Кореи и Японии, в связи с историей сношений России с этими странами. III : По коммерческой географии Восточной Азии и истории торговли Дальнего Востока] / Н. В. Кюнер. - Владивосток : Тип. Вост. ин-та, 1913. - 2, 36 с. Тираж 124 экз.

Держатели документа: Российская государственная библиотека; Российкая национальная библиотека.

56. Отчет Омского коммерческого училища за 1911/12 учебный год. - Омск : [б. и.], [1913].

Держатели документа: Библиотека Государственного архива Омской области. 
57. Отчет о состоянии учебно-воспитательной части Иркутского коммерческого училища за 1911/12 учебный год : 4-й год существования уч-ща. - Иркутск : [б. и.], 1913. - 59 с.

Держатели документа: Государственный архиВ Иркутской области; Российская государственная библиотека.

58. Пушелатский Л. М. Учебник бухгалтерии и счетоводства / Л. М. Пушелатский. - Иркутск : [б. и.], 1913. $-264,53 \mathrm{c}$.

Держатели документа: Научная библиотека Иркутского государственного университета.

59. Устав ссудо-сберегательной кассы служащих в Омском коммерческом училище. - Омск : [б. и.], 1913. - 10 c.

Держатели документа: Российская государственная библиотека; Российская национальная библиотека.

60. Устав Частного мужского коммерческого училища баронессы М. Г. Розен в г. Чите : [Утв. 20 окт. 1908 г.]. - Чита, [1913]. - 16 с.

Держатели документа: Российская государственная библиотека.

61. Устав Читинской городской торговой школы. - Чита : [б. и.], 1913. - 20 с.

Держатели документа: Читинский областной краеведиеский музей.

62. Шапошников В. С. Программа преподавания в Восточном институте по предметам счетоводства и товароведения / В. С. Шапошников. - Владивосток : Тип. Вост. ин-та, 1913. - 14 с. Тираж 121 экз. Кн. летопись, 1913, № 19050.

\section{$\infty$}

63. Колотилин А. П. Книга для орфографических и грамматических упражнений по русскому языку. 2017. T. 18, № 3. С. 443-464 
Вып. 4: Курс 2-го класса Омского коммерческого училища / А. П. Колотилин. - Омск : Тип. «Иртыш», 1914. - 36 с. Тираж 1000 экз.

Держатели документа: Российская государственная библиотека; Российская национальная библиотека.

64. Отчет о состоянии учебно-воспитательной части Иркутского коммерческого училища за 1912/13 учебный год : 5-й год существования уч-ща. - Иркутск : [б. и.], 1914. - 117 с.

Держатели документа: Государственный архиВ Иркутской области; Российская государственная библиотека; Российская национальная библиотека.

65. Отчет торговых классов Омского биржевого общества за 1912/13 и 1913/14 учебные годы. - Омск : [б. и.], 1914. -47 с.

Держатели документа: Новосибирская государственная областная научная библиотека; Библиотека Государственного архива Омской области; Российская государственная библиотека.

66. Устав Общества распространения коммерческого образования в Сибири. - Томск : Тип. Н. И. Орловой, 1914. - 11 с. Тираж 500 экз.

Держатели документа: Российская национальная библиотека.

\section{cescox}

67. Законопроект и закон о преобразовании первого Сибирского коммерческого училища цесаревича Алексея в городе Томске в первое Сибирское среднее политехническое училище цесаревича Алексея в городе Томске и устав училища. - Томск : Тип. Приюта и Дома трудолюбия, 1915. - VI, 63 с. Тираж 500 экз.

Держатели документа: Российская государственная библиотека; Российская национальная библиотека. 
68. Колотилин А. П. Книга для орфографических и грамматических упражнений по русскому языку. Вып.5 / А. П. Колотилин. - 2-е изд. - Омск : Тип. «Иртыш», 1915. - 4, 47 с. Тираж 1000 экз.

Держатели документа: Российская государственная библиотека; Российская национальная библиотека.

69. Отчет Владивостокского коммерческого училища за 1913/14 учебный год с добавлением данных из неизданных отчетов 1910-1913 учебных годов : отчет. - Владивосток : Тип. газ. «Далекая окраина», 1915. - VI,151, CV с. Тираж 300 экз.

Держатели документа: Российская государственная библиотека; Российская национальная библиотека.

70. Отчет об учебно-воспитательной деятельности коммерческого училища П. К. Щелкунова в селе Черемхове Иркутской губернии за 1914/15 учебный год : 3-й год существования уч-ща. - Иркутск : Тип. М. П. Окунева, 1915. - 54 с.

Держатели документа: Иркутская областная публичная библиотека им. И. И. Молчанова-Сибирского; Научная библиотека Иркутского государственного университета; Государственный архив Иркутской области; Российская государственная библотека.

71. Отчет о состоянии учебно-воспитательной части Иркутского коммерческого училища за 1913/14 учебный год : 6-й год существования уч-ща. - Иркутск : Тип. П. И. Макушина и В. М. Посохина, 1915. $4,107 \mathrm{c.}$

Держатели документа: Научная библиотека Иркутского государственного университета; Государственный архи Иркутской области; Российская государственная библиотека.

72. Программы трехклассных торговых школ с двумя приготовительными классами Министерства торговли и промышленности : Обществ. распростра2017. T. 18, № 3. С. 443-464 
нение коммер. образования в Сибири. - Томск : Тип. Приюта и Дома трудолюбия, 1915. - 149 с. Тираж 2000 эк3. Министерство торговли и промышленности. Кн. летопись. 1915. № 17335.

73. Розинов И. Б. Учебные программы. Ведения Министерства торговли и промышленности. Торговая школа собрания приказчиков в городе Владивостоке / И. Б. Розинов. - Владивосток : Тип. газ. «Дал. Восток», 1915. - 60 с. Тираж 200 экз. Кн. летопись. 1916. № 417.

74. Устав первой Сибирской торговой школы Томского городского общественного управления. Томск : Тип. Сиб. т-ва печ. дела, 1915. - 11 с. Тираж 200 экз.

Держатели документа: Российская государственная библиотека; Россииская национальная библиотека.

75. Устав торговой школы собрания приказчиков в городе Владивостоке. - Владивосток : Тип. газ. «Дал. Восток», 1915. - 22 с. Тираж 150 экз.

Держатели документа: Российская национальная библиотека.

76. Шапошников В. С. Сравнительные таблицы русских метрических, английских, американских, японо-корейских и китайских мер и монетных паритетов / В. С. Шапошников. - Владивосток : Тип. Вост. ин-та, 1915. - 4, 34 с. Отт. из Изв. Вост. ин-та, 1914/15 акад. г.. Т. 59, вып.1. Тираж 400 экз.

Держатели документа: Омская государственная областная научная библиотека им. А. С. Пушкина; Российская национальная библитека.

\section{c cof}

77. Кохановский Н. И. Политическая экономия. Вып. 3 : Особенная часть. Гл. 1-3 / Н. И. Кохановский. - Владивосток : [б. и.], 1916. - IV,104 с. 
Держатели документа: Российская национальная библиотека.

78. Красноярская городская торговая школа за 3 года ее существования : С сент. 1913 г. по авг. 1916 г. Красноярск : Тип. Н. Г. Титовскаго и К, 1916. - 120 с.

Держатели документа: Красноярская краевая универсальная научная библиотека; Библиотека Красноярского краеведческого музея; Библиотека Государственного архива Красноярского края.

79. Общие сведения и программы для поступления в школу. Торговая школа Новониколаевского биржевого общества. - Томск : Тип. Приюта и Дома трудолюбия, 1916. - 31 с. Тираж 500 экз.

Держатели документа: Российская начиональная библиотека.

80. Отчет Общества вспомоществования бедным учащимся частного коммерческого училища Колокольниковых в Тюмени за 1915 год. - Тюмень : Тип. Л. И. Альтшуллера, 1916. - 25 с.

Держатели документа: Научная библиотека Тюменского областного краеведческого музея.

81. Отчет о состоянии учебно-воспитательной части в иркутских торговых классах Иркутского биржевого общества за 1915 учебный год. - Иркутск : [б. и.], 1916. - 33 c.

Держатели документа: Иркутская областная публичная библиотека им. И. И. Молчанова-Сибирского.

82. Отчет о состоянии учебно-воспитательной части Иркутского коммерческого училища за 1914/15 учебный год : 7-й год существования уч-ща. - Иркутск : [б. и.], 1916. - 111 с.

Держатели документа: Государственный архиВ Иркутской области; Российская государственная библиотека; Российская национальная библиотека. 
83. Розинов И. Б. Учебные программы торговых классов собрания приказчиков в городе Владивостоке в ведении Министерства торговли и промышленности / И. Б. Розинов ; Изд. торг. классов. - Владивосток : Тип. газ. «Дал. Восток», 1916. - 21 с. Тираж 200 экз. Кн. летопись. 1916. № 16498.

84. Устав Омского коммерческого института. Омск : Тип. «Печ. искусство», 1916. - 13 с.

Держатели документа: Российская национальная библиотека.

85. Устав Тобольской городской торговой школы : утв. 30 сент. 1914 г. - Тобольск : Тип. Губерн. упр., 1916. - 16 с.

Держатели документа: Библиотека Тобольского историко-архитектурного музея-заповедника; Российская государственная библиотека; Российская национальная библиотека.

86. Устав торговой школы Новониколаевского биржевого общества. - Томск : Тип. Приюта и Дома трудолюбия, 1916. - 17 с. Тираж 200 экз.

Держатели документа: Российская государственная библиотека; Российская национальная библиотека.

87. Устав торговых классов собрания приказчиков в городе Владивостоке. - Владивосток : Тип. газ. «Дал. Восток», 1916. - 16 с. Тираж 200 экз.

Держатели документа: Российская государственная библиотека; Российская национальная библиотека.

\section{c) $4 x$}

88. Отчет Омской городской торговой школы за 1915/16 учебный год. - Омск : [б. и.], 1917.

Держатели документа: Библиотека Государственного архива Омской области. 


\section{8}

89. Отчет Попечительного совета Тобольской городской торговой школы за первый учебный 1916/17 год ее существования. - Тобольск : Губерн. тип., [1918]. - 15 с. - Тираж 200 экз.

Держатели документа: Научная библиотека Тобольского историко-архитектурного музея-заповедника; Российская национальная библиотека.

\section{c cofcot}

90. Очерк семилетней деятельности Коммерческого училища Черемховского уездного района, основанного П. К. Щелкуновым (1912-1913 и 1919(?)1919 гг.). - Иркутск : Тип. Макушина и Посохина, 1919. - 98 с. Тираж 500 экз.

Держатели документа: Омская государственная областная научная библиотека им. А. С. Пушкина.

\section{Б. I.}

91. Извлечение частного коммерческого училища Колокольниковых в Тюмени и программа за старший приготовительный класс училища. - Тюмень : [б. и.], б. г. - 13 с.

Держатели документа: Научная библиотека Тюменского областного краеведческого музея.

92. Кохановский Н. И. Политическая экономия. Вып.1: Введение : Лекции, чит. в Вост. ин-те / Н. И. Кохановский. - 4-е изд. - Владивосток : Тип. Вост. ин-та, б. г. - IV, 80 с. Тираж 198 экз.

Держатели документа: Российская государственная библиотека; Российская национальная библиотека.

93*. Проект устава коммерческого училища в г. Томске. - Томск : Типография Н. Я. Беляева, б. г. 15, [1] с. ; 20 см. - Нет тит. л. 
Держатели документа: Томская областная универсальная научная библиотека им. А. С. Пушкина.

94. Устав частного коммерческого училища баронессы М. Г. Розен в Чите. - Чита : [б. и.], б. г. - 16 с.

Держатели документа: Читинский областной краеведческий музей.

Вступит. заметка и подгот. к публ. Д. Я. Маӥдачевского 